\title{
The Unforeseen Ethical Issues and Respective Consequences in Lending Process: Albanian Banking System Case
}

\author{
Mag. Dott. Ardita Todri \\ Faculty of Economics, Elbasan \\ University of Elbasan "Aleksander Xhuvani" \\ "Ex-Former House , Elbasan, Albania \\ E-mail: ardita.todrigmail.com \\ Mobile:+355 692841581; Fax:+355 5452556
}

Doi:10.5901/mjss.2013.v4n9p387

\section{Abstract}

For more than two decades the Albanian banking system has worked in a mutual stewardship context based on trust by reflecting real business risks and ethical considerations from an important part of its risk-taking activities from one side and from the other one the welfare of the borrowing customers in good and bad times as its major concern. In other words, the trust is the ethical basis of banking and vital for the survival of a long run banking industry. Therefore, it can be confirmed that the banking success story in Albania is dedicated to its good partnership strategy and prudent management to the money collected and lend regardless the practices through which they were carried out. Precisely, this research investigates and analyses the ethical issues of current lending process in Albanian banking system in the quality of most crucial activity for the banks own selves and most essential one for that fragile economy.

\section{Introduction}

The Albanian banking system has been developed on completely commercial principles as long as it deemed reasonable and necessary for the parties of interests. Already the entire banking philosophy has evolved initiating from the communication lines, targets, products, services, etc and finalizing with the performance standards. But the question remains whether the evolution of the $\mathrm{a} / \mathrm{m}$ banking system is still ethical?

Thus, in this paper is explored the commercial dimension of the international banking group's affiliates pertaining to the Albanian banking system from a different point of view: the ethical one. The research based on 250 (good performing and no) borrowers with more than one credit line used for business and retail purposes (randomly selected from the Credit Registry) in different banks, as they are obligated to use more frequently the banking services. The findings argued on unethical actions especially related to loan proposal process and their impact on credit rating under the national unified standard (NUS).

\subsection{Data Collection Methodology}

This research analyzed the qualitative and quantitative data collected directly from the 250 (standard and no) borrowers. An apposite questionnaire was developed to reveal and understand the real Albanian banking system business ethical issues and delivered to the mentioned customers via e-mail (by making clear data usage and the anonymity preservation). The responses were compared with the respective banks credit policies as well as were analysed by using SPSS-16 version in terms of validity and reliability.

The a/m questionnaire was organised in two parts. The first part refers to the individuals or self-employed borrowers (retail business) while the second one refers to the businesses borrowers by containing qualitative and quantitative questions regarding loan application, appraisal, and proposal process. In any case, they were asked to mark the level of ethics in each evaluation cell on a 5-point scale.

\subsection{Research Results}

The research results have shown that borrowers aren't fully satisfied in terms of credit granting ethics from second level 
banks even why they act on important international banking groups' names. Particularly the keenest problematic appears the loan proposal process. Furthermore by using the same data it was studied the relation that exists between the top three ethical issues revealed in the loan proposal process and credit rating under national unified standard (NUS).

\section{The ethical issues of lending process}

Currently lending process in the Albanian banking system is bureaucratic, thus, a lots of time and expenses are need to pass from loan application process to the proposal one. By this way, it involves many people and systems especially focused in loan appraisal process. Through the latter, banks take important decisions and responsibilities above the trust investment by also investing trust on investors/borrowers. Although these relations are based on mutual trust they reflect ethical issues inside. In our case revealed that the major part of ethical issues derived from loan appraisal process are transmitted to the proposal one. But once the first bears the bank's risk strategies and conservatism the ethical issues should be accepted to some extend.... But they become worrying when are transmitted to the second one by hampering the interested parties to accomplish their missions. Logically, the ethical issues lead to borrower's dissatisfaction, by causing lending reduction and impact on the overall loan portfolio performance.

The following results show that the non-performing borrowers are more sceptics regarding the loan appraisal and ultimately to the proposal process.

Table.1. Ethical issues statistics

\begin{tabular}{|l|c|}
\hline Ethical issues & Research Results \\
\hline Customers aren't informed about loan appraisal process & $89,2 \%$ \\
\hline Bankers aren't comprehensive as they discuss by using technical terms & $87,6 \%$ \\
\hline The personal bankers/account managers influence the customer's loan product selection & $86 \%$ \\
\hline The loan application fee is high & $78 \%$ \\
\hline Bankers provide special rates for friends and relatives & $74,4 \%$ \\
\hline Delays in proposal delivery & $68,8 \%$ \\
\hline Collateral underestimation & $67,6 \%$ \\
\hline Residencies preferred as additional collaterals & $64 \%$ \\
\hline Customer pays the notarization fee of the collateral release & $61,6 \%$ \\
\hline The project revenues are underestimated and credit limits offered are lower & $60.8 \%$ \\
\hline Loans in currencies GBP, CAD and CHF aren't provided & $57,2 \%$ \\
\hline $\begin{array}{l}\text { Same interest rates are offered for housing loans independently from the amount requested } \\
\text { for first, second homes, etc... }\end{array}$ & $54,4 \%$ \\
\hline Cash collateralized loans do not imply special rates & $48,4 \%$ \\
\hline Personal and housing loans request a second guarantor & $47,6 \%$ \\
\hline Guarantors are requested even with lower revenues than the loan applicants & $46,4 \%$ \\
\hline Grace period is rarely accepted & $43,6 \%$ \\
\hline The bankers do not consult less expensive solutions in case of financial difficulties & $39,2 \%$ \\
\hline Credit grant can be provided by good relations with bankers & $34 \%$ \\
\hline Lack of funds noticed & $32 \%$ \\
\hline Bailiff practices are abusive & $31,2 \%$ \\
\hline Notifications send in delay & $26 \%$ \\
\hline Guarantors aren't informed for the respective consequences & $21,60 \%$ \\
\hline Extra-revenues generated & $14 \%$ \\
\hline Official and confidential balances sheets are requested for the evaluation of loan proposal & $12,80 \%$ \\
\hline
\end{tabular}

Source: Research results

\section{Lending activity in Albania during 2012}

Albanian economy is still fragile even it has marked a slow growth mostly thanks of lending, and for this reason is requested a continuous support from the national banking system. Generally the statistics show that more liquidity is needed for a short-term period (followed from long and mid-term loans) from Government sector, businesses (small, medium and corporate) as well as individuals. The business target group request these funds for working capital, 
overdrafts, especially in All, Usd and Euro, should be mentioned that lending in other currencies is almost insignificant. Whereas retail target group use the funds for the purchase of durable / non-durable goods, overdrafts provided in the currencies All, Usd and Euro what explains the outcome of our questionnaire regarding the lending in other currencies. Therefore inevitably, can be argued that bankers by pursuing the bank's strategy influence on the selection of loan product as evidenced from our questionnaire.

The mid and long term loans instead are used from the business to enable investments in machineries and appliances, real estate, etc. while retail prefer the mid and term loans for real estate and entrepreneurship investment purposes.

Worth to light that retail loans weighted interest rates in same foreign currencies (ALL,USD) and products are higher than the businesses loans (see Table. $2 \& 3$ ) excluding the real estate's loans which support the construction business. The latter, is largely developed the last 10 years and applies sales only in Euro currency.

By all means, the loans in the foreign currencies USD and EURO are more used (as can be noticed in Table. 4). Again our questionnaire results can be confirmed. However, this constitute an unethical behaviour, retail loans in the Albanian banking system portfolio's are more numerous than the business loans and perform even better than the latter. It shouldn't be forgotten that retail business is crucial for the Albanian economy and sensitive considering the circumstances under which it operates, exactly for these reasons it should be continuously promoted and not hindered. Therefore, Albanian banking system should accurately reflect the a/m results consequences.....

Table. 2. Retail business weighted interest rates

\begin{tabular}{|c|c|}
\hline $\begin{array}{c}\text { Retail (individuals) } \\
\text { loans }\end{array}$ & $\begin{array}{c}\text { Weighted Interest rate for } \\
\text { new loans (\%) }\end{array}$ \\
\hline ALL & 13.50 \\
\hline Overdraft & 14.62 \\
\hline Non-durable goods & 12.43 \\
\hline Durable goods & 7.96 \\
\hline Real estate & 16.87 \\
\hline Business activity & \\
\hline US\$1 & 8.25 \\
\hline Overdraft & 8.43 \\
\hline Non-durable goods & 3.56 \\
\hline Durable goods & 2.76 \\
\hline Real estate & \\
\hline Business activity & \\
\hline EURO 2 & 6.50 \\
\hline Overdraft & 7.14 \\
\hline Non-durable goods & 6.20 \\
\hline Durable goods & 5.49 \\
\hline Real estate & 7.61 \\
\hline Business activity & \\
\hline & \\
\hline
\end{tabular}

Source: Albanian Association of Banks

Table. 3. Business loans weighted interest rate

\begin{tabular}{|c|c|}
\hline Businesses loans & $\begin{array}{c}\text { Weighted Interest rate for new } \\
\text { loans (\%) }\end{array}$ \\
\hline ALL & \\
\hline Overdraft & 9.88 \\
\hline Working capital & 10.02 \\
\hline
\end{tabular}

1 Usd/All exchange rate 105.85 as per end of 2012

${ }^{2}$ Euro/All exchange rate 139.58 as per end of 2012 


\begin{tabular}{|c|c|}
\hline $\begin{array}{c}\text { Machineries and } \\
\text { appliances }\end{array}$ & 9.52 \\
\hline Real estate & 10.91 \\
\hline US\$ & 7.07 \\
\hline Overdraft & 7.28 \\
\hline Working capital & 9.00 \\
\hline $\begin{array}{c}\text { Machineries and } \\
\text { appliances }\end{array}$ & 9.00 \\
\hline Real estate & 6.93 \\
\hline EURO & 7.91 \\
\hline Overdraft & 8.08 \\
\hline Working capital & 8.37 \\
\hline $\begin{array}{c}\text { Machineries and } \\
\text { appliances }\end{array}$ & \\
\hline Real estate & \\
\hline
\end{tabular}

Source: Albanian Association of Banks

In accordance with the mentioned lending interest rates the new loan's structure as per year 2012 is reflected as following:

Table. 4. New loan's structure during 2012

\begin{tabular}{|c|c|c|c|c|c|c|}
\hline \multirow{3}{*}{$\begin{array}{c}\text { (in '000 } \\
\text { ALL) }\end{array}$} & \multicolumn{6}{|c|}{ New Loan's Structure as per Year 2012} \\
\hline & \multicolumn{2}{|c|}{ Short-term Loans } & \multicolumn{2}{|c|}{ Mid-term Loans } & \multicolumn{2}{|c|}{ Long-term loans } \\
\hline & ALL & $\begin{array}{l}\text { Foreign } \\
\text { Currency }\end{array}$ & ALL & $\begin{array}{l}\text { Foreign } \\
\text { Currency }\end{array}$ & ALL & Foreign Currency \\
\hline January & $3,641,010$ & $7,668,383$ & 997,735 & $2,343,593$ & $1,614,736$ & $2,219,709$ \\
\hline February & $5,302,932$ & $5,809,775$ & $1,144,434$ & $4,449,183$ & $1,312,429$ & $1,968,046$ \\
\hline March & $6,212,222$ & $9,261,816$ & $1,561,421$ & $2,933,205$ & $1,545,372$ & $3,327,252$ \\
\hline April & $5,919,271$ & $6,150,189$ & $1,219,065$ & $1,847,543$ & $1,041,863$ & $1,745,654$ \\
\hline May & $6,421,679$ & $8,820,263$ & $3,596,340$ & $1,703,321$ & $1,392,411$ & $2,370,094$ \\
\hline June & $4,911,474$ & $5,774,043$ & $1,631,151$ & $1,960,759$ & $1,750,906$ & $4,730,417$ \\
\hline July & $6,177,635$ & $8,202,171$ & $1,379,425$ & $1,940,016$ & $1,573,761$ & $3,188,003$ \\
\hline August & $4,277,073$ & $7,999,765$ & $1,731,159$ & $2,838,096$ & $2,355,986$ & $2,432,294$ \\
\hline September & $4,804,114$ & $4,699,990$ & $1,206,267$ & 935,927 & $2,008,818$ & $1,442,796$ \\
\hline October & $14,522,404$ & $4,603,727$ & $1,832,678$ & 796,219 & $1,859,908$ & $1,564,986$ \\
\hline November & $7,364,653$ & $9,698,134$ & $1,073,255$ & 898,651 & $4,692,270$ & $1,847,728$ \\
\hline December & $9,830,700$ & $10,910,769$ & $2,002,636$ & $3,994,096$ & $1,546,109$ & $3,780,582$ \\
\hline Total & $79,385,167$ & $89,599,025$ & $19,375,565$ & $26,640,608$ & $22,694,569$ & $30,617,561$ \\
\hline
\end{tabular}

Source: Albanian Association of Banks

Beyond the ethical issues revealed in the Albanian banking system, during the year 2012 the lending activity is shrunk (see Table. 5\&6), as result of three main causes:

1. Neighbourhood crises (Italian and Greek). The foreign direct investments and trade relations with these countries are vital for the Albanian economy by representing the main contributors to the country GDP growth rate in previous years without skipping the impact of remittances from the albanian workers.

2. The increase of non-performing loan rates (as per the $\mathrm{a} / \mathrm{m}$ reasons the business and individuals were unable to respond to the financial commitments on time).

3. The conservative measures undertaken from the Albanian banking system pertaining to the lending criteria by being focused especially on collection process. 
Table. 5. Foreign Currency Lending Trend during 2012

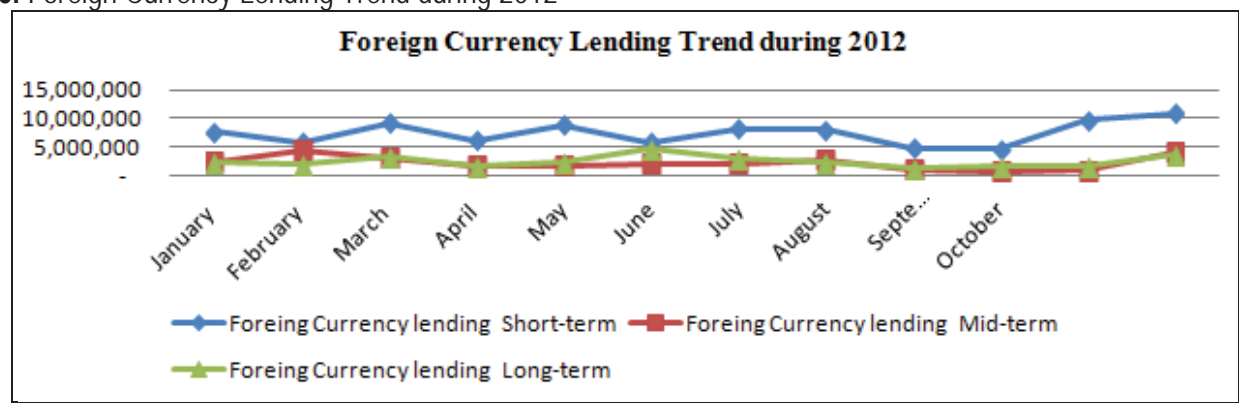

Source: Albanian Association of Banks

The banks have reasonable seen to lend in foreign currencies in short-term and reduce the lending in mid-long term.

Table. 6. Local Currency Lending Trend during 2012

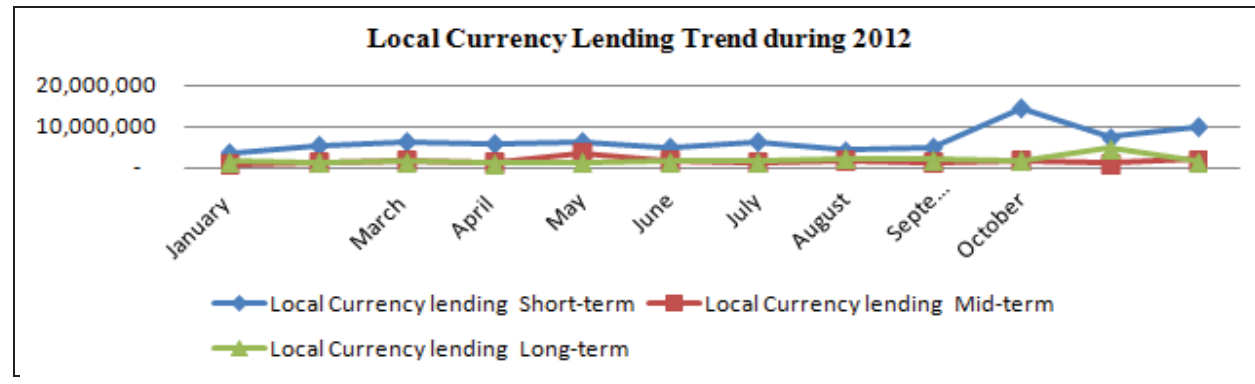

Source: Albanian Association of Banks

The opposite is noticed in local currency lending, short and long term lending is increased while mid term lending is decreased.

\section{Loans portfolio performance analysis during 2012}

As foreseen, despite the mentioned troubles Albanian banking system has continued to extend the granting activity although in a more conservative way by giving priority to the sectors that haven't posed repayment problems.

The outstanding loans figures by the end of 2012 are presented in Table. 7.

Table.7. Outstanding loans balance figures as per the year 2012

\begin{tabular}{|l|c|}
\hline \multicolumn{1}{l}{} & in mil. ALL \\
\hline Description & Dec-12 \\
\hline Outstanding loan balance & $\mathbf{5 7 7 , 8 1 6}$ \\
\hline 7 day & 44,158 \\
\hline 7 day - 1 month & 18,512 \\
\hline 1-3 months & 36,627 \\
\hline 3-6 months & 50,431 \\
\hline 6-12 months & 103,382 \\
\hline 1-5 years & 192,981 \\
\hline 5 years + & 131,724 \\
\hline
\end{tabular}

Source: Albanian Association of Banks 


\subsection{The analysis of loan portfolio quality during 2012}

The credit rating to portfolio outstanding has deteriorated by becoming worrying, compared with the previous year results. Currently, standard loans to portfolio outstanding ratio is estimated $65.3 \%$, special mentioned loans to portfolio outstanding ratio is estimated $8 \%$, substandard loans to portfolio outstanding ratio is estimated $9.9 \%$, doubtful loans to portfolio outstanding ratio is estimated $4.7 \%$ and the lost loans to portfolio outstanding ratio is estimated $6.5 \%$ where the previous year results were $73.5 \%, 9.33 \%, 8.03 \%, 4.08 \%$ and $5.1 \%$ respectively. During this year is observed an increase of doubtful and lost loans trend (see Table. 8).

Table. 8. Non-performing loans trend during 2012

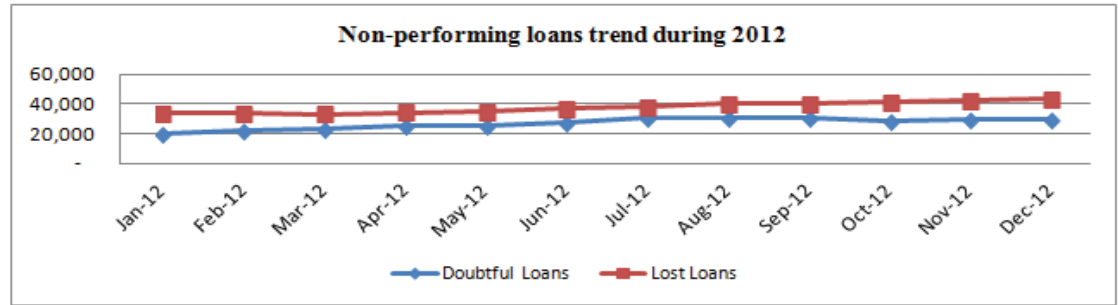

Source: Albanian Association of Banks

The matter is: If the ethical issues observed in our research influence loan repayment schedule (performance), so the credit rating under national unified standard?

For this purpose is analysed (with SPSS -16 version) the relation that exists between top three ethical issues (derived from the research statistics) such as independent variables:

1. Customers do not have information regarding the loan appraisal process (X1);

2. Bankers aren't comprehensive even when explain as they use technical terms (X2);

3. The personal bankers/account managers influence customer's loan product selection (X3).

and the 250 loans credit rating (dependent variable-Y) by using the contamination rule in the due days criteria as requested in the national unified standard.

The stepwise regression analysis results showed that exist a good relation (see Table. 9) between credit rating (dependent variable-Y) and bankers influence on the customer's loan product selection (independent variable-X3).

Table. 9. Model Summary

\begin{tabular}{|c|c|c|c|c|}
\hline \multicolumn{5}{|c|}{ Model Summary } \\
\hline Model & $\mathrm{R}$ & R Square & Adjusted R Square & Std. Error of the Estimate \\
\hline 1 & $.705^{\mathrm{a}}$ & .498 & .496 & .89028 \\
\hline
\end{tabular}

a. Predictors: (Constant), Bankers Influence the loan product selection (X3)

Source : Stepwise Regression Analysis

Also the ANOVA test confirms the a/m regression goodness at 95\% confidence level (see Table. 10).

Table. 10. ANOVA test

ANOVA $^{b}$

\begin{tabular}{|c|c|c|c|c|c|}
\hline Model & Sum of Squares & $\mathrm{df}$ & Mean Square & $\mathrm{F}$ & Sig. \\
\hline Regression (a) & 194.752 & 1 & 194.752 & 245.714 & $.000^{\mathrm{a}}$ \\
\hline Residual & 196.564 & 248 & .793 & & \\
Total & 391.316 & 249 & & & \\
\hline
\end{tabular}

a. Predictors: (Constant), Bankers Influence the loan product selection (X3)

b. Dependent Variable: Credit Rating $(Y)$

Source : Stepwise Regression Analysis 
Due to the logical collinearity, the variables (X1) and (X2) are excluded from the model as per Table. 11 result's.

Table. 11. Excluded Variables

Excluded Variables ${ }^{b}$

\begin{tabular}{|c|c|c|c|c|c|}
\hline \multicolumn{1}{|c|}{ Model } & Beta In & $\mathrm{t}$ & Sig. & $\begin{array}{c}\text { Partial } \\
\text { Correlation }\end{array}$ & $\begin{array}{c}\text { Collinearity } \\
\text { Statistics }\end{array}$ \\
\cline { 5 - 7 } & & & & Tolerance \\
\hline $\begin{array}{l}\text { Bankers explanation is not } \\
\text { comprehensive (X2) }\end{array}$ & $-.007 \mathrm{a}$ & -.063 & .950 & -.004 & .150 \\
\hline $\begin{array}{l}\text { Customers do not have information } \\
\text { regarding loan appraisal process (X1) }\end{array}$ & $-.029 \mathrm{a}$ & -.463 & .644 & -.029 & .515 \\
\hline
\end{tabular}

a. Predictors in the Model: (Constant), Bankers Influence the loan product selection (X3)

b. Dependent Variable: Credit Rating $(Y)$

\section{Source: Stepwise Regression Analysis}

The stepwise regression analysis gives same results at 95\% confidence level under different coefficients when additional ethical issues derived from the research were used. It can be confirmed that, the ethical issues in loan appraisal and proposal process directly impact (in our case negatively) the credit rating (with the increase of unethical actions in the lending process level's credit rating deteriorates).

\section{Discussion, Limitations and Conclusion}

Despite, this study has several limitations related to the research and analysis which may be addressed to further studies, such as: specialized research instrument, country banking characteristics as well as other factors not captured.... should be highlighted the importance of indications given to the Albanian banking system above the influence of the ethical issues in credit rating under the national unified standard (NUS). As a consequence, they don't imply only obstacles for loan repayment and credit deterioration but also increase the credit provisioning in both standards (NUS and IFRS) by transmitting troubles in the banking profit \&loss statement's, capital adequacy and ultimately threaten the lending process.

Hence, the ethical issues of lending activity and its performance should be accurately analyzed and kept under control through the review of credit risk management strategy aiming a better management by avoiding additional troubles in the Albanian banking system...

More than ever, under these circumstances the $\mathrm{a} / \mathrm{m}$ system should resize the entire lending process under an alternative approach, the ethical one, in accordance with customer care, lending evolution prospective and its strategic goals.

Concretely, the banks should be opened and more flexible while:

$>$ approaching credit applications by charging lower costs;

$>$ rapidly concluding the loan proposals;

$>$ correctly estimating the project revenues;

providing grace period and credit limits in the requested currencies;

$>$ offering tailored pricings in respect of credit purposes,

$>$ establishing ethical investing strategies, etc

and adapting to the business exigencies in respect of a more solid commercial relationship for a better future..... This can be understood as transparency, responsibility, faith, opportunity, cooperation and advocacy to the next.

Obviously that, pursuing a more ethical approach will require sacrifices under the current regulatory framework, specifically in:

$>$ risk appetite;

$>$ capital allocation;

on behalf of the banking offer which will spontaneously push the banking competition in another level: less commercial and more aware toward important values such as: social responsibility, environment, ethics, etc even initially 
risking in order to provide gradual sustainable economic growth to the country and latter on prosperity in a wide range of population.

And all this leads to a restructuring of the whole albanian banking system, especially placing forward new challenges the existing banks by constituting solid standards on banking business doing. From the other side remains the regulator's responsibility the massive financial education, the providence of facilities in terms of financial and legal framework for the ethical lending by restoring the trust to the parties of interest.

\section{References}

Albanian Association of Banks . Available: http://www.aab.al/en/announcements.php.

Alexander, E.C. (2002). "Consumer reactions to unethical service recovery", Journal of Business Ethics, 36(3), 223-237.

Athanassopoulos, A. (1998). "Another look into the agenda of customer satisfaction: focusing on service providers own and perceived viewpoints", International Journal of Bank Marketing, Vol. 15 No. 7.

Bentler, P., Bonnet, D. (1980). "Significance tests and goodness of fit in the analysis of covariance structures", Psychological Bulletin, Vol. 88, pp. 588-606.

Farell, A. M. (2012). The Politics of Blood: Ethics, Innovation and the Regulation of Risk. Cambridge University Press, (Chapters $2,3,5,8)$.

Folkes. V. S., Kamins, M. A. (1999). "Effects of information about firms' ethical and unethical actions on consumers' attitudes", Journal of Consumer Psychology, 8(3), 243-259.

Hair, J.F., Anderson, R.E., Tatham, R.L., Black, W.C. (1998). Multivariate Data Analysis, Prentice Hall, Englewood Cliffs, NJ.

Kane, E.J. (2022)."Using deferred compensation to strengthen the ethics of financial regulation", Journal of Banking and Finance, 26, 1919-1933.

Koehn, D. (2005). "Integrity as a Business Asset", Journal of Business Ethics 58, 125-136.

Osterhus, T.L., 1997. "Pro-social consumer influence strategies: When and how do they work?",Journal of Marketing 61 (4), 16-29.

Randall, D.M., Gibson, A.M. (1990). "Methodology in Business Ethics Research: A Review and Critical Assessment," Journal of Business Ethics, 9, 457-471.

Reynolds, J.N., Newel, E. (2011). Ethics in Investment Banking, Palgrave Macmillan, (Chapters 2,3,4,7,8).

Rust, R.T. and Zahorik, A.J. (1993)."Customer satisfaction, customer retention, and market share", Journal of Retailing, Vol. 69 No. 2, pp. 193-215.

Sekaran, U. (1992). Research Methods For Business, John Wiley and Sons, Inc., New York, NY.

Spitzeck, H., Dierksmeier, C., Pirson, M. (2012). Banking with Integrity: The Winners of the Financial Crisis? Palgrave Macmillan, (Chapter 2,3,4, 5,6,7,8, 12).

Svensson, G.,Wood. G.(2003)."The Dynamics of Business Ethics: a Function of Time and Culture -Cases and Model", Management Decision 41(3), 350-361.

Taylor, S. (1997). "Assessing regression-based importance weights for quality perceptions and satisfaction judgments in the presence of higher order and/or interaction effects", Journal of Retailing, Vol. 73 No. 1, pp. 135-59.

Tabachnick, B.G., Fidell, L.S. (1996). Using Multivariate Statistics, HarperCollins, New York,NY.

Todri, A. (2012). "Atypical" Banks : A Value Driven Ban king in Albania, International Journal of Business and Commerce, Vol.2, No.4: Dec 2012[64-77], ISSN: 2225-2436

TSENG, H., Duan, C., Tung, H. Kung, H. (2009). "Modern Business Ethics Research: Concepts, Theories, and Relationships", Journal of Business Ethics, 91(4). 587-597. 